\title{
APLIKASI SMART CITY - GOVERNANCE : TEKNOLOGI PELAPORAN TEMPAT KEJADIAN PERKARA SINKRONISASI SISTEM INFORMASI GEOGRAFIS SECARA REAL TIME
}

\author{
A. Sumardin ${ }^{1}$, Erwin Gatot ${ }^{2}$ \\ Teknik Informatika STMIK AKBA ${ }^{1}$, Teknik Komputer STMIK AKBA ${ }^{2}$ \\ Email: andisumardin@akba.ac.id ${ }^{1}$, erwingatot@akba.ac.id ${ }^{2}$
}

\begin{abstract}
ABSTRAK
Aplikasi smart city pelaporan TKP ini akan mewadahi masyarakat untuk ikut terlibat dalam melaporkan setiap kejadian perkara yang ditemukan dengan mengambil gambar melalui camera smartphone selanjutnya diunggah. Lokasi tempat mengunggah tersebut akan ditandai untuk sinkronisasi dengan teknologi sistem informasi geografis yang terlapor kepada pihak kepolisian secara langsung mendapatkan data dan lokasi kejadian secara real time dan akurat. Dalam teknologi smart city ini nantinya setiap laporan yang disampaikan oleh masyarakat akan termonitoring baik di polres ataupun di polsek-polsek, sehingga akan dengan mudah menentukan siapa yang paling dekat dari lokasi kejadian maka dialah yang ditugaskan untuk penanganan. Selain itu, dalam sistem juga akan dibaca lokasi-lokasi puskesmas maupun puskesmas pembantu sebagai alternatif pertama untuk pertolongan.
\end{abstract}

Kata Kunci: TKP, SIG, Teknologi Mobile, Smart City.

\section{ABSTRACT}

This smart city TKP reporting application will accommodate the community to be involved in reporting any case events found by taking pictures through the camera smartphone then uploading. The location of the upload will be marked to synchronize with the geographic information system technology that is reported to the police to directly obtain the data and location of the incident in real time and accurately. In this smart city technology, every report submitted by the community will be monitored both at the police station and at the police station, so that it will be easy to determine who is the closest to the location of the incident and who is assigned to handle it. In addition, the system will also read the locations of health centers and auxiliary health centers as the first alternative for help.

Keywords: TKP, GIS, Mobile Technology, Smart City.

\section{Pendahuluan}

Pemilihan teknologi mobile sangat berdasar, hal ini didukung oleh infrastrukur jaringan internet yang semakin menjangkau, hampir diseluruh lapisan masyarakat. Fokus penelitian ini semakin beralasan untuk membangun aplikasi smart city pelaporan tempat kejadian perkara
(TKP). Sinkronisasi kedalam sistem informasi geografis (SIG) ini akan membantu untuk memonitoring laporan yang masuk dengan memvisualkan melalui peta yang menjadi kehebatan dari teknologi ini. Teknologi sistem informasi geografis akan memetakan koordinat lokasi dan posisi kejadian yang dilengkapi 
foto dari laporan masyarakat (Citizen Journalist). Teknologi pendukungnya memanfaatkan teknologi web dengan menerapakan eXtreme Programming (XP) sebagai framework pengembangan sistem.

\section{Tinjauan Pustaka}

\subsection{Smart City}

Dalam konteks kota, smart dimaksudkan adalah bangunan perkotaan digital. Pada tahun 2000, Smart city diadopsi oleh Europe 2020 Strategy yang lebih kepada ruang perkotaan yang berkelanjutan. Beberapa peneliti dan institusi telah memberikan definsi untuk smart city seperti Caragliu, Del Bo, and Nijkamp (2011), Su et al. (2011),McAllister, Hall, Partridge, and Hallam (2005), dan Dameri (2013). Sebagai contoh Caragliu et al. (2011) mengatakan bahwa kota akan "smart" ketika investasi sumber daya manusia dan sosial, transportasi, dan ICT dapat menggerakan pertumbuhan ekonomi yang berkelanjutan dan meningkatkan kualitas hidup dengan pengelolaan sumber daya alam yang bijaksana melalui peran pemerintah.

\subsection{Smart Governance}

Menyimak karakteristik smart city tersebut, maka dapat dilihat bahwa smart governance merupakan salah satu jenis dari smart city. Smart Governance dapat didefinisikan sebagai bagian dari smart city yang terkait dengan masa depan pelayanan publik, yaitu mengenai efisiensi yang lebih baik, kepemimpinan komunitas berkerja secara mobilitas dan perbaikan secara berkelanjutan melalui inovasi [1]

\subsection{Tempat Kejadian Perkara}

Tempat kejadian perkara itu tidak hanya mempunyai pengertian sebagai tempat dimana kejahatan itu terjadi. Tempat kejadian perkara itu adalah "semua tempat kejadian peristiwa baik yang berupa kejahatan, pelanggaran, maupun kecelakaan biasa yang lazim menjadi urusan polisi”. Bawengan (1999) yang memberikan pengertian tempat kejadian perkara adalah "tempat dimana pembuat telah melakukan segala sesuatu yang kemudian mengakibatkan terjadinya tindak pidana". Akan tetapi, pengertian tempat kejadian perkara menurut Petunjuk Pelaksanaan No. Pol : JUKLAK/04/II/1982 Kepolisian R.I. disebutkan bahwa:Tempat kejadian perkara (TKP) adalah tempat dimana suatu tindak pidana dilakukan / terjadi dan tempat-tempat lain di mana tersangka dan atau korban dan atau barang-barang bukti yang berhubungan dengan tindak pidana tersebut, dapat ditemukan

\section{4 eXtreme Programming}

eXtreme Programming (XP) merupakan agile methods yang paling populer saat ini. XP digunakan untuk mengatasi masalah requirements yang tidak jelas dan sering berubah-ubah (vague and volatile requirements). XP berjalan berdasarkan 4 values. Keempat values tersebut adalah communication, simplicity, feedback, dan courage [4]

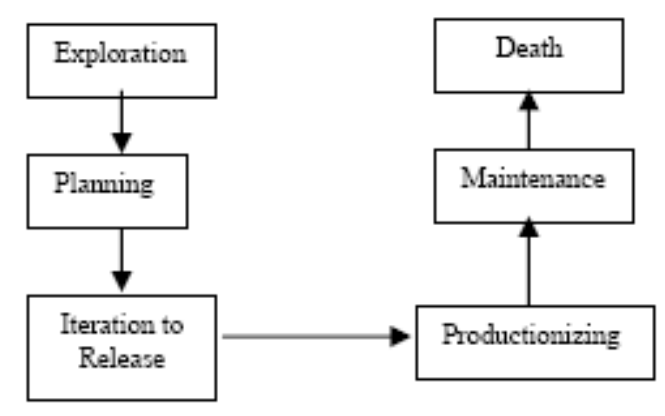

Gambar 1 Siklus eXtreme Programming 


\subsection{Sistem Informasi Geografis}

Sistem infomasi geografis menurut [2] adalah sistem yang berbasis komputer yang digunakan untuk mengambil, mengumpulkan, memeriksa, menggabungkan, memanipulasi dan menampilkan data menggunakan peta yang telah terdigitasi. Sistem Informasi Geografi (SIG) adalah sistem komputer yang dapat menyimpan dan menggunakan data untuk menggambarkan tempat-tempat dipermukaan bumi [3].

SIG juga merupakan sebuah alat bantu manajemen berupa informasi berbantuan komputer yang berkait erat dengan sistem pemetaan dan analisis terhadap segala sesuatu serta peristiwaperistiwa yang terjadi di muka bumi. Teknologi SIG mengintegrasikan operasi pengolahan data berbasis database yang biasa digunakan saat ini, seperti pengambilan data berdasarkan kebutuhan dan analisis statistik dengan menggunakan visualisasi yang khas serta berbagai keuntungan yang mampu ditawarkan melalui analisis geografis melalui gambargambar petanya

\section{Metode Perancangan}

\subsection{Aktivitas Pengembangan}

Dalam pelaksanaannya, ke-4 artefak tersebut akan dilakukan proses masing-masing sebagai berikut :

1. Planning

Aktivitas planning pada model proses XP berfokus pada mendapatkan gambar fitur serta fungsi dari perangkat lunak yang akan di bangun. Pada aktifitas ini di mulai dengan membuat kumpulan cerita atau gambaran yang diberikan klien yang kemudian akan menjadi gambaran dasar dari prangkat lunak.
2. Design

Aktivitas desain dalam pengembangan aplikasi bertujuan untuk mengatur pola logika dalam sistem. Desain pada model proses Extreme Programming menjadi panduan dalam membangun prangkat / lunak yang didasari dari cerita klien sebelumnya

3. Coding

Coding proses pengkodean program yang mana nantinya akan menerapkan konsep pair programming dimana setiap tugas sebuah modul di kembangkan oleh tim.

4. Testing

Tes Tahap di mana sudah dilakukan pengkodean program terus dilakukan uji coba terhadap sistem yang sudah selesai. XP menerangkan perbaikan masalah kecil dengan segera mungkin akan lebih baik dibandingkan menyelesaikan masalah pada saat akan mencapai tingkat akhir

\subsection{Use Case Diagram}

Level aktor yang terlibat dalam apliasi ini ditunjukan pada 2 use case berikut ini :

1. Use Case Kepolisian

Use case diagram pada gambar 1 ditunjukkan aktor dari pihak kepolisian dalam hal ini level Polisi Resort atau Polres dan Polisi Sektor atau Polsek sebagai admin yang mengelola, memonitoring setiap laporan yang disampaikan masyarakat melalui aplikasi TKP ini. Pada level ini ke 2 aktor tersebut saling berkoordinasi dan bekerjasama dalam menanggapi laporan masyarakat melalui aplikasi. Polres dan polsek dapat dengan mudah melihat laporan kejadian dalam bentuk peta. Lokasi kejadian menjadi pertimbangan untuk menentukan polres/polsek terdekat terhadap lokasi 
kejadian untuk menindaklanjutin. Termasuk tugas tersebut menentukan pusat kesehatan yang mana yang nantinya untuk segera memberikan pertolongan pertama jika kejadian. Setiap laporan yang disampaikan maupun yang telah ditangani menjadi tugas utama aktor (polres dan polsek) yang memiliki akses dalam level ini.

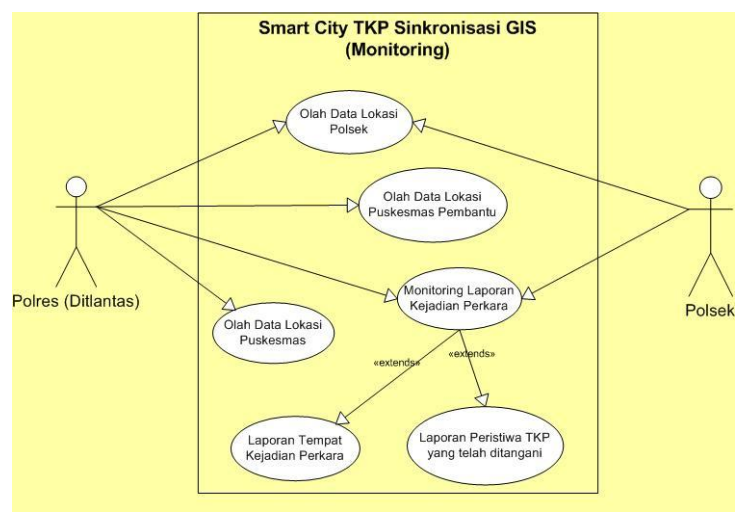

Gambar 2 Use case diagram Admin

2. Use Case Masyarakat

Aktor penting selain aktor dari pihak kepolisian adalah aktor masyarakat sebagai end user terpenting yang diminta partisipasinya untuk melaporkan kejadian perkara yang mereka temui dilapangan. Aktor masyarakat ini memiliki akses untuk melaporkan kejadian dengan cara memcapture dalam bentuk foto peristiwa yang ditemui. Setiap hasil take foto ini secara otomatis akan merekam posisi koordinat baik latitude maupun longitude. Hal ini sebabkan karena setiap user/masyarakat jika ingin melaporkan fitur GPS dalam smartphone mereka harus dalam keadaan aktif yang ditunjukan pada gambar 2. Seorang user yang ingin melaporkan harus dipastikan benar-benar berada dilokasi kejadian. Hal tersebut dikarenakan posisi pengembalian foto menjadi area koordinat lokasi kejadian.

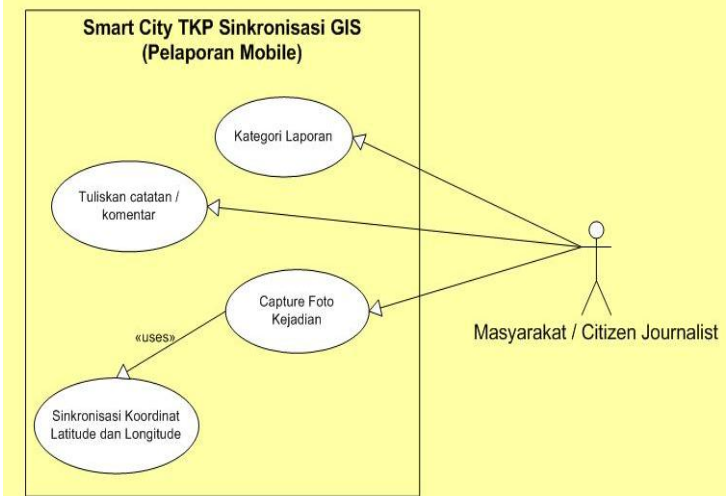

Gambar 3 Use Case Masyarakat

\section{Hasil dan Pembahasan}

Hasil implementasi penelitian berdasarkan analisis yang telah dilakukan yang mencakup implementasi sistem serta tahap-tahap pengujian dari sistem yang telah dibuat untuk mengetahui tingkat keberhasilan dari sistem tersebut.

a. Hasil pengujian sistem

Pengujian yang dilakukan meliputi pengujian black box terhadap segala fitur dan fungsi dalam sistem yang ditunjukan dalam tabel 1 .

Tabel 1 Hasil Pengujian

\begin{tabular}{|l|l|}
\hline \multicolumn{1}{|c|}{ Butir Uji } & \multicolumn{1}{|c|}{$\begin{array}{c}\text { Hasil } \\
\text { Pengujian }\end{array}$} \\
\hline Menampilkan lokasi Polsek & Berhasil \\
\hline $\begin{array}{l}\text { Menampilkan lokasi } \\
\text { Puskesmas }\end{array}$ & Berhasil \\
\hline $\begin{array}{l}\text { Menampilkan lokasi } \\
\text { puskesmas pembantu }\end{array}$ & Berhasil \\
\hline Mengolah data member & Berhasil \\
\hline $\begin{array}{l}\text { Memonitoring laporan } \\
\text { kejadian perkara }\end{array}$ & Berhasil \\
\hline $\begin{array}{l}\text { Menampilkan laporan } \\
\text { peristiwa TKP yang dimarker }\end{array}$ & Berhasil \\
\hline $\begin{array}{l}\text { Melakukan capture foto } \\
\text { kejadian }\end{array}$ & Berhasil \\
\hline $\begin{array}{l}\text { Sinkronisasi koordinat latitude } \\
\text { dan longitude }\end{array}$ & Berhasil \\
\hline
\end{tabular}




\section{b. Mobile Device}

Dalam melaporkan kejadian perkara oleh masyarakat maka dipilihlah teknologi berbasis mobile. Teknologi mobile ini memungkinkan end user / masyarakat menggunakan smartphone dimanapun dan kapanpun saat akan melaporkan TKP. Bentuk laporan yang bisa dilakukan dapat berupa foto, audio maupun video dengan menyertakan komentar atau catatan atas kejadian yang ditemui/dilaporkan. Desain interface yang digunakan dirancangan semudah mungkin untuk lebih mudahkan masyarakat dalam menggunakannya seperti ditunjukan pada gambar 4.

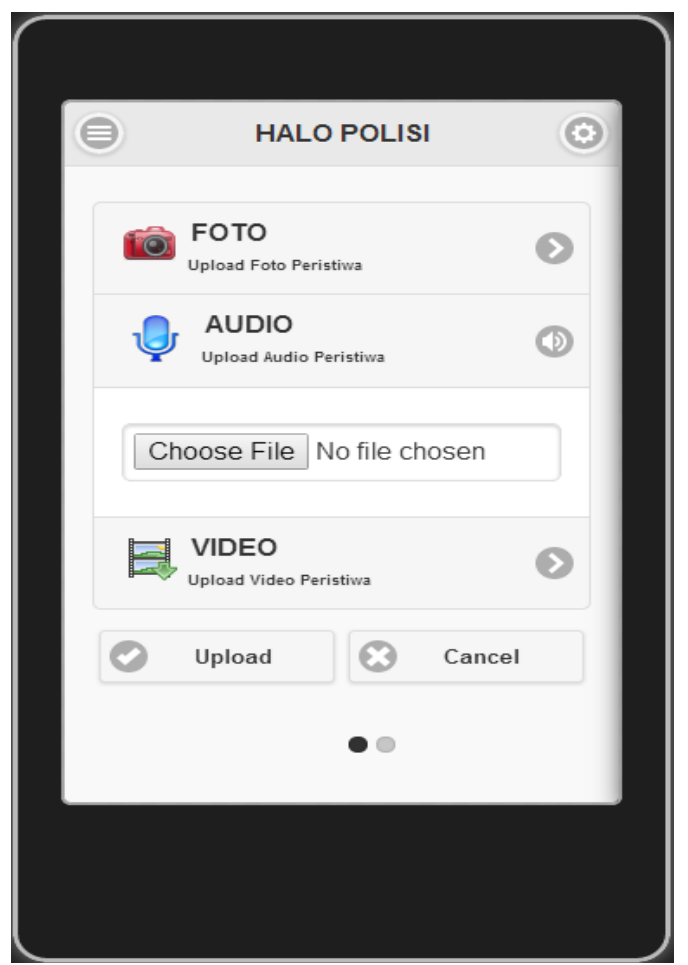

Gambar 4 Aplikasi TKP Mobile

c. Tampilan web based

Tampilan desktop/web based untuk menampilkan informasi yang full layar. Sehingga user dengan bebas untuk mengakses setiap fitur dan menu yang tersedia dalam sistem. Gambar maupun detail produk telah disajikan dengan sangat

$\begin{array}{lrr}\text { sederhana } \quad \text { sehingga } & \text { diharapkan } \\ \text { user/member } & \text { familier } & \text { dalam } \\ \text { menggunakannya. } & & \end{array}$

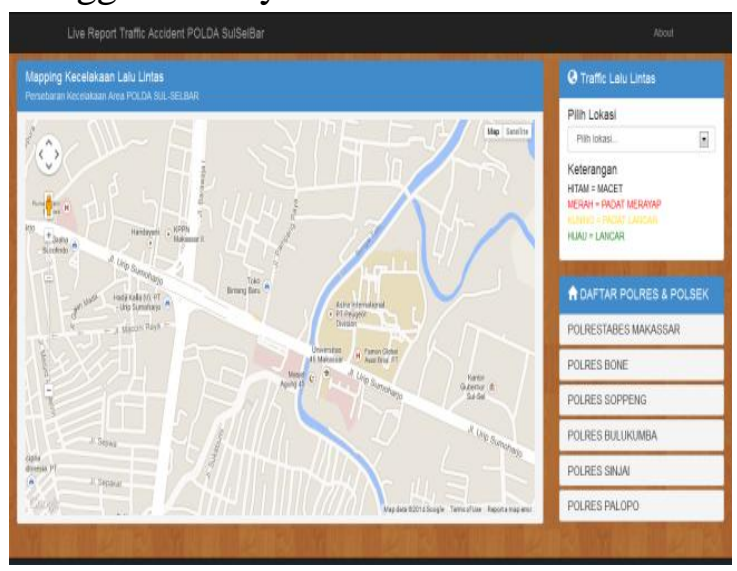

Gambar 5 Halaman Admin Kepolisian

\section{d. Script Capture Foto Peristiwa}

Halaman end user sebagai tampilan yang diakses menggunakan smartphone memiliki fitur utama untuk mengcapture foto peristiwa di TKP ditunjukkan dengan skrip pada gambar 6 .

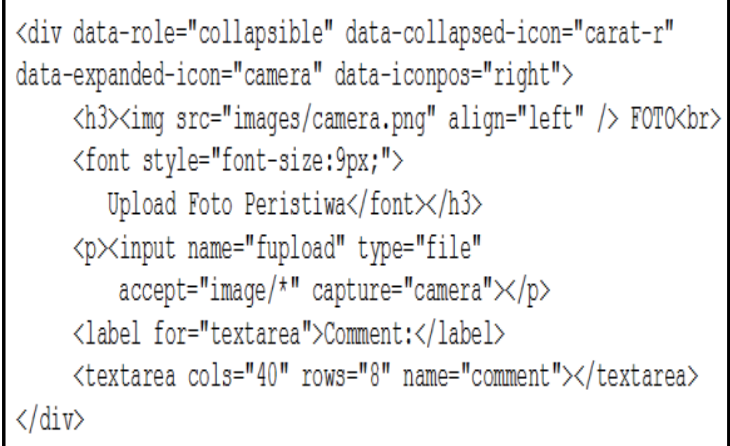

Gambar 6 Script Capture Foto Peristiwa

Pada skrip yang ditunjukkan pada gambar 6 secara langsung akan mengaktifkan aplikasi kamera yang ada di smartphone pengguna.

\section{e. Script GPS Latitude dan Longitude}

Setiap foto yang dicapture melalui aplikasi TKP ada direkam koordinat latitude dan longitudenya seperti yang ditunjukkan pada coding gambar 7 . 


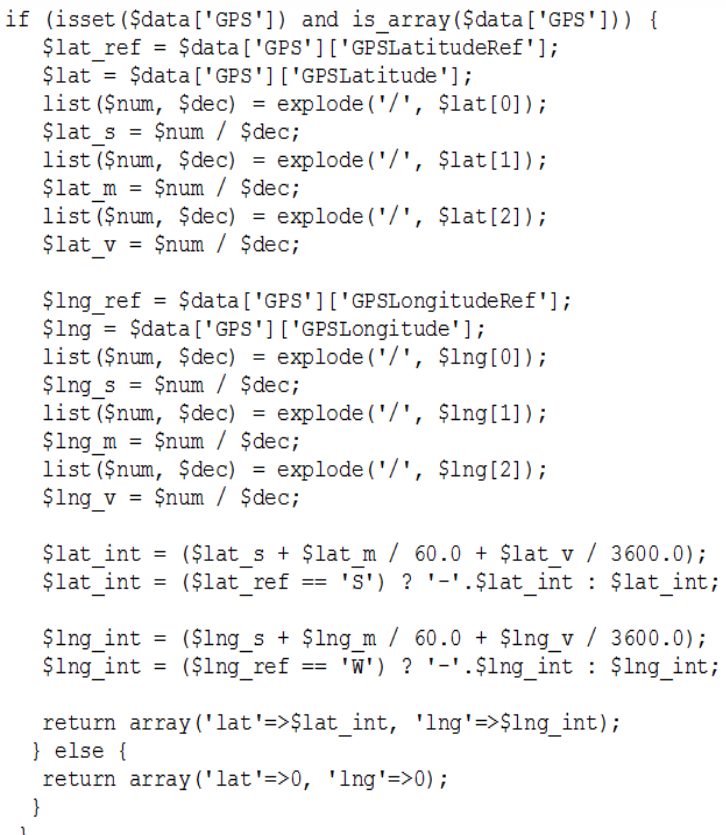

Gambar 7 Script GPS Latitude dan Longitude

Koordinat latitude dan longitude tersebut berdasarkan hasil informasi dari GPS pada smartphone yang diaktifkan sesaat sebelumnya mengambil foto. Posisi koordinat yang diambil bersama foto menyesuaikan lokasi end user / masyarakat yang melaporkan kejadian.

\section{Kesimpulan}

Berdasarkan penelitian yang telah dilakukan, dapat disimpulkan bahwa :

Aplikasi smart city pelaporan tempat kejadian perkara ini telah dilaksanakan penelitian pendahuluan, pemodelan sistem, pembuatan desain dan perancangan sistem untuk memudahkan pihak berwenang dan pihak terkait pelaporan kejadian perkara yang melibatkan unsur masyarakat secara partisipatif di Kabupaten Bone, Sistem ini akan dikembangkan menggunakan teknologi web responsive dengan terintegrasi google maps sebagai penggunaan teknologi geografis

\section{Daftar Pustaka}

[1] Di Maio, A. (2010). Vice President and Analyst at Gartner Research.

[2] Turban, R. P. (2005). Introduction to Information Technology. John Wiley \& Sons, Inc

[3] Heywood, I. (2002). An introduction to geographical information systems 2nd Edition. New Jersey: Prentice Hall

[4] P., A., Salo, J. R., \& J., W. Agile Software Development Methods: Review dan Analysis. Finland: VVT Publication 478 